\title{
Genetic Studies on Parental Diversity in Relation to Yield of Promising Hybrids in Upland Cotton (Gossypium hirsutum L.)
}

\author{
V. Udaya ${ }^{1 *}$ and Rajesh S. Patil ${ }^{2}$ \\ ${ }^{1}$ College of Agriculture, Dharwad, University of Agricultural Sciences, Dharwad, India \\ ${ }^{2}$ Agriculture Research Station, Dharwad Farm, University of Agricultural Sciences, \\ Dharwad, India \\ *Corresponding author
}

\section{A B S T R A C T}

\section{Keywords \\ Genetic diversity, Mahalanobis $\mathrm{D}^{2}$ statistic, Clusters, Upland cotton \\ Article Info \\ Accepted: \\ 07 December 2018 Available Online: 10 January 2019}

\begin{abstract}
Genetic diversity in 13 parental upland cotton genotypes for 13 yield and yield attributing traits was studied using Mahalanobis $\mathrm{D}^{2}$ statistic. The parental hirsutum genotypes grouped in 5 clusters based on the traits investigated. The pattern of grouping of parental genotypes revealed the presence of considerable diversity in the genetic material. The inter cluster distance was greater than intra cluster distance, revealing considerable amount of genetic diversity among parental genotypes investigated. The forces other than geographical origin may have been responsible for genetic divergence among the parental genotypes. The cross CPD-462 $\times$ SCS-1061 yielded the highest seed cotton yield, which is of medium genetic divergence. In this study, it was interesting to note that rather than highly divergent genotypes, medium divergence resulted in superior yield, indicating that highly diverse parents were not imperative to heterosis.
\end{abstract}

\section{Introduction}

Cotton (Gossypium spp.) is one of the most important crops among the natural fibre crops and back bone of Indian textile industry. It provides rural livelihood to a large number of people through cultivation. India ranks first in area (122.35 lakh ha) and production (377 lakh bales). Among four linted cotton species, upland cotton (Gossypium hirsutum L.) is a predominant species of cotton across the globe as well as in India. By virtue of its wider adaptability, higher yield and good fibre quality, it gradually replaced Asiatic diploid cotton and is grown in irrigated as well as rainfed conditions. However, Indian cotton productivity $\left(560 \mathrm{~kg} \mathrm{ha}^{-1}\right)$ is lower than world productivity of $788 \mathrm{~kg} \mathrm{ha}^{-1}$ (Anon., 2018). Plant breeders usually rely on genetic variation between parents to create unique gene combinations necessary for higher yield and to produce superior cultivars. Genetic distance plays an important role in selection of parental genotypes for hybridization. Within a certain limit, hybridization of diverse parents is expected to enhance the level of heterosis in hybrids and generate wide range of variability in segregating generations (Joshi and Dhawan, 1966). Although the choice of parents is often the most important decision in a breeding 
program, little is known about the importance of parental genetic distance in successful cotton cultivar development. It is widely assumed that genetically diverse parents facilitate the creation of superior progeny, though only a few studies have examined the relationship between parental genetic distance and the creation of successful cultivars. In theory, mating of distantly related parents will produce greater number of transgressive segregants than mating of closely related genotypes. However, for many crops, yield improvement has even come from mating closely related genotypes. In this context, the objective of this study was to determine the importance of parental genetic distance in hybrid potential realisation. Such information could be useful in identifying optimal breeding strategies for cotton improvement.

In bajra, Gupta et al., (2017) observed that higher seed yield in $F_{1}$ is directly correlated with genetic distance. Similar results were obtained by Manjarrez-Sanoval et al., (1997) in soybean and Cowen and Frey (1987) in oat. However, in contrast, Kisha et al., (1997) reported that there is larger genetic variance in related soybean parents than in closely related parents and concluded that genetic distance could not accurately predict the genetic variance for any given cross. In studies with wheat, Cox and Murphy (1990) and Souza and Sorrells (1991) reported that relationship between genetic distance and variance varied among traits and populations.

\section{Materials and Methods}

The study was conducted in Agriculture Research Station, Dharwad Farm, University of Agricultural Sciences, Dharwad. Forty hybrids were obtained by crossing 8 lines and 5 testers in $\mathrm{L} \times \mathrm{T}$ fashion and all 40 hybrids along with 13 parental genotypes were evaluated simultaneously in RCBD design in 3 replications. Uniform spacing of $90 \times 20 \mathrm{~cm}$ for parental genotypes and $90 \times 40 \mathrm{~cm}$ for $F_{1}$ was followed. The hybrids and parents were randomised amongst themselves and were sown in separate but adjacent plots. Each entry was sown in two rows of 4.80 meters length. The crop was raised under rainfed condition. All agronomic management practices according to recommended package of practices were followed to raise a good crop. Suitable plant protection measures were carried out to control pests and diseases at appropriate time. In each genotype, observations on 5 randomly selected plants were recorded for 13 traits viz., days to 50 per cent flowering, plant height $(\mathrm{cm})$, number of monopodia per plant, number of sympodia per plant, sympodial length at 50 per cent plant height $(\mathrm{cm})$, number of bolls per plant, boll weight $(\mathrm{g})$, number of seeds per boll, seed index $(\mathrm{g})$, ginning outturn $(\%)$, lint index $(\mathrm{g})$, SPAD values (Soil Plant Analysis Development) and seed cotton yield (kg/ha). The genetic diversity of parental genotypes was worked out by using Mahalanobis $\mathrm{D}^{2}$ statistic as described by Rao (1952). On the basis of $\mathrm{D}^{2}$ values, parental genotypes were grouped into different clusters by employing Tocher method as outlined by Rao (1952).

\section{Results and Discussion}

The analysis of variance indicated significant differences among all the genotypes for all the characters studied showing the existence of considerable genetic diversity among genotypes. Hence, further analysis was carried out for relative magnitude of $\mathrm{D}^{2}$ values for all the characters and all genotypes. Eight lines and five testers, which were diverse in terms of geographical location, plant type and with economic traits like boll weight, number of bolls, seed cotton yield and fibre properties were used for present study (Table 1). Clustering of genotypes is presented in Figure 1 and Table 2. All the genotypes were grouped into five clusters, indicating the presence of 
diversity for different traits. The cluster I and cluster II had the highest number of genotypes followed by clusters III, IV and V, which were solitary with a single genotype in each cluster. In this present investigation it was very clear that genetic diversity was not fully related to the geographical diversity. This was in accordance with the results of Singh and Bains (1968), Singh et al., (1971), Singh and Gill (1994), Sumathi and Nadarajan (1994), Pushpam et al., (2004), Kulkarni and Nanda (2006), Satish et al., (2009), Parresuman and Patil (2014) and Handi et al., (2017). In this present investigation formation of distant solitary clusters may be due to the fact that geographical barriers might be due to the fact that geographical barriers prevent gene flow or intensive natural and human selection for diverse and adoptable gene complexes. The pattern of grouping has indicated that diversity need not be necessarily related to geographical diversity and it may be the outcome of several other factors like natural selection, human selection, exchange of breeding material, genetic drift and environmental variation.

Intra and inter cluster distances are given in Table 3. The parental genotypes investigated were found to be diverse in nature. The maximum intra cluster distance was recorded in cluster II (12.54), while it was lowest in clusters III, IV and V (0.00) since, they were solitary clusters. The maximum inter cluster distance was observed between clusters I and IV (74.58) followed by between clusters I and III (69.13). These results suggest maximum divergence existed between genotypes of cluster I and cluster II indicating the fact that the genotypes found in one cluster differed entirely from the genotypes present in the other cluster. The cross CPD-462 $\times$ SCS-1061 yielded the highest seed cotton yield, where the parents were moderately diverse genetically (i.e., from clusters I and II). This result was in accordance with Arunachalam and Bandopadhyay (1984), Altaher and Singh
(2003) and Kulkarni and Nanda (2006), where they proved experimentally that a greater number of heterotic combinations with high level of heterosis were from the parents grouped into moderate divergence groups. The results obtained from clustering pattern agree with hypothesis of moderate divergence for the best heterotic combination.

\section{Contribution of characters towards divergence}

The diversity among the 13 parental lines was measured by employing $\mathrm{D}^{2}$ statistic. The contribution of each character towards divergence is presented in Table 4 and Figure 2. Among the 13 characters studied, the contribution of seed index $(56.13 \%)$ was higher towards divergence followed by number of seeds per boll (12.83\%), lint index $(8.97 \%)$, number of monopodia per plant $(6.41 \%)$, plant height $(3.85 \%)$, number of bolls per plant $(3.85 \%)$, boll weight $(3.85 \%)$, seed cotton yield $(2.56 \%)$, sympodial length at 50 per cent plant height $(1.28 \%)$ and SPAD meter value $(0.28 \%)$. Days to 50 per cent flowering, ginning outturn and number of sympodia per plant had no contribution.

\section{Analysis of cluster means}

The mean values for different clusters for all the characters are presented in Table 5. The genotypes in cluster I (61.09) had minimum days to 50 per cent flowering and maximum days was found in genotypes falling under cluster V (63.56). With respect to plant height, minimum height was found in cluster I (99.40 $\mathrm{cm}$ ) and maximum height was found in cluster IV $(135.67 \mathrm{~cm})$. In case of number of monopodia per plant, lowest and highest values were found in cluster IV (0.20) and cluster I (0.92), respectively. For sympodia per plant, lowest and highest numbers were found in cluster $\mathrm{V}(14.40)$ and cluster IV (18.60), respectively. For boll weight, lowest 
and highest values were found in cluster $\mathrm{V}$ $(3.27 \mathrm{~g})$ and cluster III $(4.25 \mathrm{~g})$, respectively. In case of number of bolls per plant, lowest and highest values were found in cluster IV (7.40) and cluster I (10.48), respectively. Lowest and highest values for seed cotton yield were in cluster IV (461.17 kg/ha) and cluster I $(800.33 \mathrm{~kg} / \mathrm{ha})$, respectively. Genotypes under cluster III $(34.94 \mathrm{~cm})$ had lowest value and cluster IV $(38.50 \mathrm{~cm})$ had highest value for sympodial length at 50 per cent plant height. The parental lines possessing lesser number of seeds per boll were included under cluster II (26.05) and the highest number, in cluster V (28.30). Cluster IV $(37.07 \%)$ and cluster III (35.50\%) recorded highest and lowest means for the trait ginning outturn. For seed index, lowest and highest values were found in cluster I $(9.69 \mathrm{~g})$ and cluster III $(11.00 \mathrm{~g})$. The highest values for lint index fell under cluster $\mathrm{V}$ and lowest values in cluster I. For SPAD meter values, highest values and lowest values fell in cluster V (39.95) and cluster IV (37.33).

Table.1 Genetic material used in the study

Lines

\begin{tabular}{|c|c|c|c|}
\hline Line No. & Genotype & Pedigree & Salient features \\
\hline L1 & FLT-36 & L-761 × Sahana & $\begin{array}{l}\text { A single cross derivative highly robust } \\
\text { genotype with high root to shoot ratio, high } \\
\text { yielding ability and good fibre properties }\end{array}$ \\
\hline L2 & FLT-44 & CPD-813 × 8-1-2 & $\begin{array}{l}\text { A single cross derivative highly robust } \\
\text { genotype with high root to shoot ratio, high } \\
\text { yielding ability and tolerance to sucking } \\
\text { pests }\end{array}$ \\
\hline L3 & FLT-31 & DC-12 IPS $\times 8-1-2$ & $\begin{array}{l}\text { A single cross derivative compact genotype } \\
\text { with high biomass, high yielding ability and } \\
\text { good fibre properties }\end{array}$ \\
\hline L4 & FLT-28 & $\mathrm{L}-761 \times \mathrm{SC}-81$ & $\begin{array}{l}\text { A single cross derivative, robust genotype } \\
\text { with high root to shoot ratio, high yielding } \\
\text { ability and good fibre properties }\end{array}$ \\
\hline L5 & SG-1 & SVHH $139 \times$ GSHB 876 & $\begin{array}{c}\text { A double cross derivative from a } \mathrm{HH} \times \mathrm{HB} \\
\text { cross. Robust plant type, relatively smaller } \\
\text { boll size than SG-2 with higher yield } \\
\text { potential }\end{array}$ \\
\hline L6 & SG-2 & SVHH $139 \times$ GSHB 876 & $\begin{array}{l}\text { A double cross derivative from a } \mathrm{HH} \times \mathrm{HB} \\
\text { cross. Highly robust plant type, big bolls } \\
\text { and with better fibre properties }\end{array}$ \\
\hline L7 & EL-1 & $\begin{array}{l}\text { Random double cross } \\
\text { between interspecific hybrids }\end{array}$ & $\begin{array}{l}\text { Compact plant type, Random double cross } \\
\text { derivative involving two HB hybrids with } \\
\text { good fibre length and strength properties }\end{array}$ \\
\hline L8 & CPD-462 & CNH-120 MB & $\begin{array}{l}\text { Selection from CNH-120MB, a good } \\
\text { combiner and high yielder }\end{array}$ \\
\hline
\end{tabular}




\section{Testers}

\begin{tabular}{|c|l|l|l|}
\hline $\begin{array}{c}\text { Tester } \\
\text { No. }\end{array}$ & Genotype & Pedigree & Salient features \\
\hline T1 & NNDC-30 & RAHH $246 \times$ JKCH 2245 & $\begin{array}{l}\text { A super-compact plant type, very high yielding, } \\
\text { medium size bolls }\end{array}$ \\
\hline T2 & NNDC-24 & Mahabeej $123 \times$ JKCH 2245 & $\begin{array}{l}\text { A robust genotype with very high yielding ability, a } \\
\text { greater number of bolls and high fibre strength to } \\
\text { length ratio. }\end{array}$ \\
\hline T3 & NNDC-59 & $\begin{array}{l}\text { Random double cross between } \\
\text { interspecific hybrids }\end{array}$ & $\begin{array}{l}\text { Random double cross derivative involving two HB } \\
\text { hybrids Compact plant type with higher boll weight }\end{array}$ \\
\hline T4 & IH-11 & A genotype from AICRP trials & Indore genotype with high yield and robust plant type \\
\hline T5 & SCS-1061 & A genotype from AICRP trials & $\begin{array}{l}\text { Raichur genotype with high yield and robust plant } \\
\text { type }\end{array}$ \\
\hline
\end{tabular}

Table. 2 Clustering of thirteen parental genotypes based on $\mathrm{D}^{2}$ analysis in cotton (G. hirsutum L.)

\begin{tabular}{|c|l|c|}
\hline Cluster & \multicolumn{1}{|c|}{ Genotypes } & Number of genotypes \\
\hline I & CPD-462, NNDC-24, NNDC-30, NNDC-59, FLT-31 & 5 \\
\hline II & IH-11, SCS-1061, EL-4, FLT-36, FLT-44 & 5 \\
\hline III & FLT-28 & 1 \\
\hline IV & SG-2 & 1 \\
\hline V & SG-1 & 1 \\
\hline
\end{tabular}

Table.3 Average intra and inter cluster distances in parental genotypes in cotton (G. hirsutum L.)

\begin{tabular}{|l|l|l|l|l|l|}
\hline & Cluster I & Cluster II & Cluster III & Cluster IV & Cluster V \\
\hline Cluster I & 10.96 & 41.34 & 69.13 & 74.58 & 30.71 \\
\hline Cluster II & 41.34 & 12.54 & 16.23 & 22.36 & 26.71 \\
\hline Cluster III & 69.13 & 16.23 & 0.00 & 8.78 & 39.10 \\
\hline Cluster IV & 74.58 & 22.36 & 8.78 & 0.00 & 39.43 \\
\hline Cluster V & 30.71 & 26.71 & 39.10 & 39.43 & 0.00 \\
\hline
\end{tabular}

Table.4 Per cent contribution of characters towards total parental diversity

\begin{tabular}{|l|c|}
\hline \multicolumn{1}{|c|}{ Character } & Characters contribution (\%) \\
\hline Days to 50\% flowering & 0.00 \\
\hline Plant height (cm) & 3.85 \\
\hline Number of monopodia per plant & 6.41 \\
\hline Number of sympodia per plant & 0.00 \\
\hline $\begin{array}{l}\text { Sympodial length at 50 per cent plant height } \\
\text { (cm) }\end{array}$ & 1.28 \\
\hline Number of bolls per plant & 3.85 \\
\hline Boll weight (g) & 3.85 \\
\hline Number of seeds per boll & 12.82 \\
\hline Seed index (g) & 56.13 \\
\hline Ginning outturn (\%) & 0.00 \\
\hline Lint index (g) & 8.97 \\
\hline Seed cotton yield (kg/ha) & 2.56 \\
\hline SPAD meter value & 0.28 \\
\hline
\end{tabular}


Table.5 Cluster mean values of yield and yield component characters in thirteen parental genotypes of different clusters in cotton $(G$. hirsutum L.)

\begin{tabular}{|c|c|c|c|c|c|c|c|c|c|c|c|c|c|}
\hline & $\begin{array}{l}\text { Days to } \\
50 \text { per } \\
\text { cent } \\
\text { flowering }\end{array}$ & $\begin{array}{c}\text { Plant } \\
\text { height } \\
(\mathrm{cm})\end{array}$ & $\begin{array}{c}\text { Monopodia } \\
\text { per plant }\end{array}$ & $\begin{array}{l}\text { Sympodia } \\
\text { per plant }\end{array}$ & $\begin{array}{c}\text { Boll } \\
\text { weight } \\
\text { (g) }\end{array}$ & $\begin{array}{l}\text { Number } \\
\text { of bolls }\end{array}$ & $\begin{array}{c}\text { Seed } \\
\text { cotton } \\
\text { yield } \\
(\mathrm{kg} / \mathrm{ha})\end{array}$ & $\begin{array}{l}\text { Sympodial } \\
\text { length at } \\
50 \text { per } \\
\text { cent plant } \\
\text { height } \\
\text { (cm) }\end{array}$ & $\begin{array}{l}\text { Number } \\
\text { of seeds } \\
\text { per boll }\end{array}$ & $\begin{array}{c}\text { Ginning } \\
\text { outturn } \\
(\%)\end{array}$ & $\begin{array}{c}\text { Seed } \\
\text { index } \\
(\mathrm{g})\end{array}$ & $\begin{array}{c}\text { Lint } \\
\text { index } \\
(\mathrm{g})\end{array}$ & $\begin{array}{l}\text { SPAD } \\
\text { meter } \\
\text { values }\end{array}$ \\
\hline $\begin{array}{l}\text { Cluster } \\
\text { I }\end{array}$ & 61.09 & 99.40 & 0.92 & 16.76 & 3.91 & 10.48 & 800.33 & 35.33 & 27.61 & 36.78 & 9.69 & 5.68 & 39.10 \\
\hline $\begin{array}{l}\text { Cluster } \\
\text { II }\end{array}$ & 62.43 & 111.56 & 0.60 & 16.97 & 4.22 & 9.45 & 728.23 & 36.11 & 26.05 & 35.73 & 10.30 & 5.73 & 38.73 \\
\hline $\begin{array}{l}\text { Cluster } \\
\text { III }\end{array}$ & 62.26 & 110.13 & 0.47 & 18.27 & 4.25 & 8.11 & 720.33 & 34.94 & 29.13 & 35.50 & 11.00 & 6.08 & 39.03 \\
\hline $\begin{array}{l}\text { Cluster } \\
\text { IV }\end{array}$ & 62.40 & 135.67 & 0.20 & 18.60 & 3.84 & 7.40 & 461.17 & 38.50 & 27.83 & 37.07 & 9.73 & 5.78 & 37.33 \\
\hline $\begin{array}{l}\text { Cluster } \\
\text { V }\end{array}$ & 63.56 & 104.93 & 0.67 & 14.40 & 3.27 & 7.51 & 508.83 & 35.78 & 28.30 & 35.98 & 10.67 & 6.10 & 39.95 \\
\hline
\end{tabular}

Table.6 List of top five crosses and their parental genetic distance

\begin{tabular}{|l|c|l|}
\hline Crosses & Seed cotton yield & $\begin{array}{l}\text { Genetic } \\
\text { distance }\end{array}$ \\
\hline CPD-462 $\times$ SCS-1061 & 1890.00 & 41.34 \\
\hline FLT-36 $\times$ SCS-1061 & 1353.83 & 12.54 \\
\hline CPD-462 $\times$ NNDC-30 & 1311.00 & 10.96 \\
\hline FLT-36 × NNDC-59 & 1266.83 & 41.34 \\
\hline FLT-36 × NNDC-24 & 1258.00 & 41.34 \\
\hline
\end{tabular}


Fig.1 Dendrogram of $\mathrm{D}^{2}$ analysis for thirteen parental genotypes for yield and yield attributing traits in cotton ( $G$. hirsutum L.)

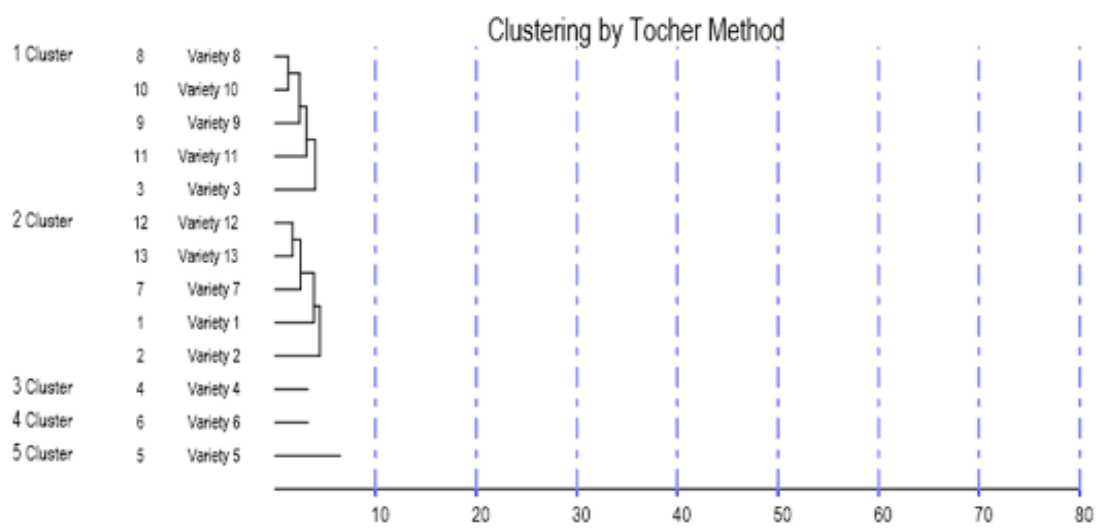

Fig.2 Per cent contribution of characters towards total parental diversity

CHARACTERS CONTRIBUTION (\%)

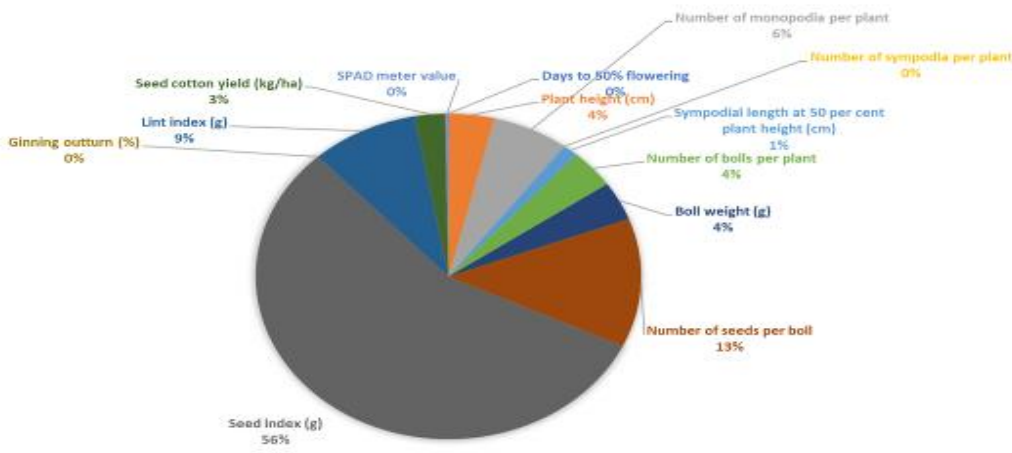

In conclusion, there was considerable amount of genetic diversity noticed in parental genotypes. The contribution of characters towards divergence indicates seed index was the major contributor followed by number of seeds per boll and lint index. Parental genotypes were grouped into 5 clusters indicating considerable amount of diversity among parental genotypes. In this investigation all top crosses were from medium diverse parents (Table 6) and it was also noticed that too much of parental genetic diversity was not imperative for cotton improvement. High heterosis can be achieved even from moderate diverse parents in cotton.

\section{References}

Altaher, A. F. and. Singh, R. P., 2003, Genetic diversity studies in upland cotton (Gossypium hirsutum L.) using two methods of clustering. J. Indian Soc. Cotton Improv., 28(3): 158-163.

Anonymous, 2018, Annu. Rep. (2016-17), All India Co-ordinated Cotton Improvement Project, 2016-2017, p. A1-A5.

Arunachalam, V. and Bandopadhyay, A., 1984, Limits to genetic divergence for 
occurrence of heterosis: Experimental evidence from crop plants. Indian $J$. Genet. 44(3): 548-554.

Cowen, N. M. and Frey. K. J., 1987, Relationship between genealogical distance and breeding behaviour in oats (Avena sativa L.). Euphytica 36: 413424.

Cox, T. S. and Murphy. J. P., 1990. The effect of parental divergence of $\mathrm{F}_{2}$ heterosis in winter wheat crosses. Theor. Appl. Genet. 79: 241-250.

Gupta, S. K., Nepolean, T., Shaikh, C. G., Rai, K., Hash, C. T., Das, R. R. and Rathore, A., 2017, Phenotypic and molecular diversity-based prediction of heterosis in pearl millet (Pennisetum glaucum L.). Crop J., 4(1): 11-21.

Handi, S. S., Ramesh, M. and Katageri, I. S., 2017, Genetic diversity studies for yield traits in upland cotton ( $G$. hirsutum L.). J. Pharma. Phytochem., 8(2): 587-593.

Joshi, A. B. and Dhawan, N. L., 1996, Genetic improvement in yield with special reference to self-fertilization crops, Indian J. Genet. 26(A): 101-113.

Kisha, T. J., Sneller, C. H. and Diers. B. W., 1997, Relationship between genetic distance among parents and genetic variance in populations of soybean. Crop Sci. 37: 1317-1325.

Kulkarni, A. A. and Nanda, H. C., 2006, Genetic diversity in upland cotton (Gossypium hirsutum L.). Indian J. Plant Genet. Resour., 19(2): 226-230.

Manjarrez-Sandoval, P., Carter, T. E., Webb, D. M. and Burton. J. W., 1997, RFLP genetic similarities estimates and coefficient of percentage as genetic variance predictors for soybean yield.
Crop Sci., 37: 698-703.

Parresuman. and Patil, R. S, 2014, Studies on genetic divergence in intra hirsutum hybrids of early segregating generation $\left(\mathrm{F}_{3}\right)$ in upland cotton (Gossypium hirsutum L.). Int. J. Dev. Res., 4(3): 781-783.

Pushpam, R., Raveendran, T. S., Devasena, N. and Ravikesavan, R., 2004, Studies on genetic diversity in upland cotton $(G$. hirsutum). J. Indian Soc. Cotton Improv., 29(2): 135-143.

Rao, C. R., 1952, Advanced Statistical Methods in Biometrical Research. John Wiley and Sons, New York, p.120.

Satish, Y., Jain, P. P. and Chhabra, B. S., 2009, Studies on genetic diversity in upland cotton (Gossypium hirsutum L.). J. Cotton Res. Dev. 23(1): 18-22.

Singh, B. B., Murty, B. R. and Jain, O. P., 1971, Nature of divergence among some varieties of upland cotton. Indian J. Genet. 31: 363-368.

Singh, J. H. and Gill, S. S., 1984, Genetic diversity in upland cotton under different environment. Indian J. Genet. 44: 506-573.

Singh, R. B. and Bains, S. S. 1968, Genetic diversity for ginning outturn and the components in upland cotton. Indian $J$. Genet. 28: 262-268.

Souza, E, and M. E. Sorrells. 1991. Prediction of progeny variation in oat from parental genetic relationships. Theor. Appl. Genet. 82: 233-241.

Sumathi, P. and Nadarajan, N, 1994, Genetic divergence in upland cotton (Gossypium hirsutum L.). J. Indian Soc. Cotton Improv., 3: 36-42.

\section{How to cite this article:}

Udaya, V. and Rajesh S. Patil. 2019. Genetic Studies on Parental Diversity in Relation to yield of Promising Hybrids in Upland Cotton (Gossypium hirsutum L.). Int.J.Curr.Microbiol.App.Sci. 8(01): 513-520. doi: https://doi.org/10.20546/ijcmas.2019.801.056 